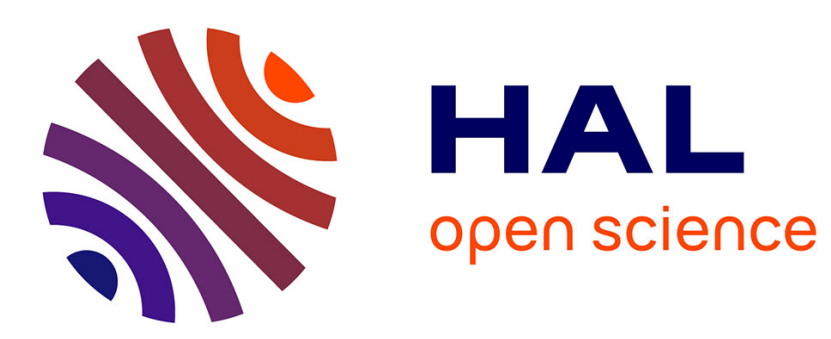

\title{
Correlating biological methods to assess Escherichia coli bacteria viability in silica gels
}

\author{
M. Blondeau, R. Brayner, F. Guyot, Thibaud Coradin
}

\section{To cite this version:}

M. Blondeau, R. Brayner, F. Guyot, Thibaud Coradin. Correlating biological methods to assess Escherichia coli bacteria viability in silica gels. Analytical Methods, 2014, 6 (8), pp.2429-2431. 10.1039/C4AY00111G . hal-01138982

\section{HAL Id: hal-01138982 https://hal.sorbonne-universite.fr/hal-01138982}

Submitted on 3 Apr 2015

HAL is a multi-disciplinary open access archive for the deposit and dissemination of scientific research documents, whether they are published or not. The documents may come from teaching and research institutions in France or abroad, or from public or private research centers.
L'archive ouverte pluridisciplinaire HAL, est destinée au dépôt et à la diffusion de documents scientifiques de niveau recherche, publiés ou non, émanant des établissements d'enseignement et de recherche français ou étrangers, des laboratoires publics ou privés. 


\title{
Correlating biological methods to assess Escherichia coli bacteria viability in silica gels
}

\author{
M. Blondeau, ${ }^{a, b}$ R. Brayner, ${ }^{c}$ F. Guyot ${ }^{d}$ and T. Coradin $* a, b$
}

The viability of Escherichia coli bacteria entrapped in silica gels can be monitored using the Alamar Blue assay and ATP-metry, two complementary methods that correlate with the traditional plate count technique while avoiding its current limitations related to cell growth conditions.

Assessment of bacterial cell viability is routinely performed using the plate count technique. This technique relies on the spreading of a cell suspension on a solid nutrient media that is kept in usual optimal growth conditions, i.e. at $37^{\circ} \mathrm{C}$ over $24 \mathrm{~h}$ for common bacteria. After this delay, each initial living cell has grown into a colony so that viability is given by the number of colony forming units (CFU) per $\mathrm{mL}$ of the starting suspension. However, there are two main situations where the plate count technique cannot be applied. The first one concerns cells whose growth conditions are uncommon, if not unknown. ${ }^{1}$ The second possibility is that cells have entered the so-called viable but non-culturable (VBNC) state where the cells are alive but have a very low metabolic activity and thus cannot be grown in usual conditions. ${ }^{2}$

Bacterial cells usually enter the VBNC state as a response to a stress situation. ${ }^{3}$ This is usually the case for Escherichia coli bacteria trapped in silica gels as they are unable to divide in the mineral network. ${ }^{4,5}$ In these conditions, their viability may not be reliably assessed by the plate count technique after extraction from the gels since this method excludes non culturable cells. Alternative methods must be found to investigate the immobilized cells, such as monitoring complex metabolisms $^{4,6}$ or genetic responses via bioluminescent reporters ${ }^{5,7}$ However, none of these approaches can be directly correlated to bacteria viability.

To address this problem, we have here adapted and evaluated two methods, the Alamar Blue test and ATP-metry measurements to silica-immobilized E. coli bacteria, and compared them to the plate count technique. The sol-gel procedure followed the previously-described aqueous route in the presence of glycerol. ${ }^{4}$ However only sodium silicate solutions $(0.8 \mathrm{M})$ were used as silica source and addition of silica nanoparticles was not performed to favor gel redispersion. Full experimental details for encapsulation and cell viability determination protocols are provided as ESI. All experiments were performed at least in triplicate.

As a reference, the CFU of the initial bacteria suspension $(\mathrm{CFU})_{0}$ was determined by plate counting. The same technique was used to determine the number of viable cells in silica gels at different ageing time $(\mathrm{CFU})_{\mathrm{t}}$ just after encapsulation $(\mathrm{t}=15$ min) and after 1,7 and 15 days. The viability rate was then calculated as $100 x(\mathrm{CFU})_{t} /(\mathrm{CFU})_{0}$. As shown in Fig. 1, a slow decay in cell viability is observed with time, reaching $c a .50 \%$ after 2 weeks.

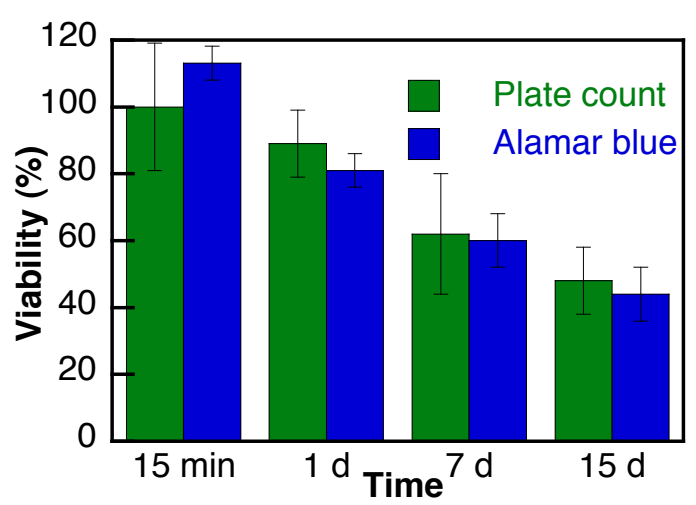

Fig. 1. Evolution of bacteria viability within silica gels using the plate count and Alamar blue techniques. Error bars correspond to standard deviation. 
The Alamar Blue assay is based on the reduction of the resazurin blue dye into a colourless hydroresorufin molecule, as a result of an oxygen-consuming metabolic pathway and therefore mainly due to cell respiration. ${ }^{8}$ It is widely used to assess viability of mammalian cells but was also applied to bacteria and yeasts. ${ }^{9}$

In a first step, a calibration curve was established between the cell number in a bacterial suspension, as determined by the plate count technique, and the reduction rate (in \%). As shown in Figure 2, a linear correlation is obtained, with a slope of 3.7 $\pm 0.410^{-7} \% . \mathrm{mL} . \mathrm{CFU}^{-1}$. The same procedure was then applied to bacteria recovered from gel resuspension after $15 \mathrm{~min}$ to 15 days ageing. A linear correlation is also obtained between cell number and \% reduction, with a slope of $3.6 \pm 0.510^{-7}$ $\%$.mL.CFU ${ }^{-1}$, i.e. similar to the reference bacterial suspension. This indicates that the aerobic respiration of bacteria is not significantly perturbed as a result of encapsulation. It also becomes possible to use the calibration curve to obtain the number of viable cells from the Alamar Blue test and to calculate the corresponding viability rate. As shown in Fig. 1, a very good correlation is obtained between this method and the plate count technique.

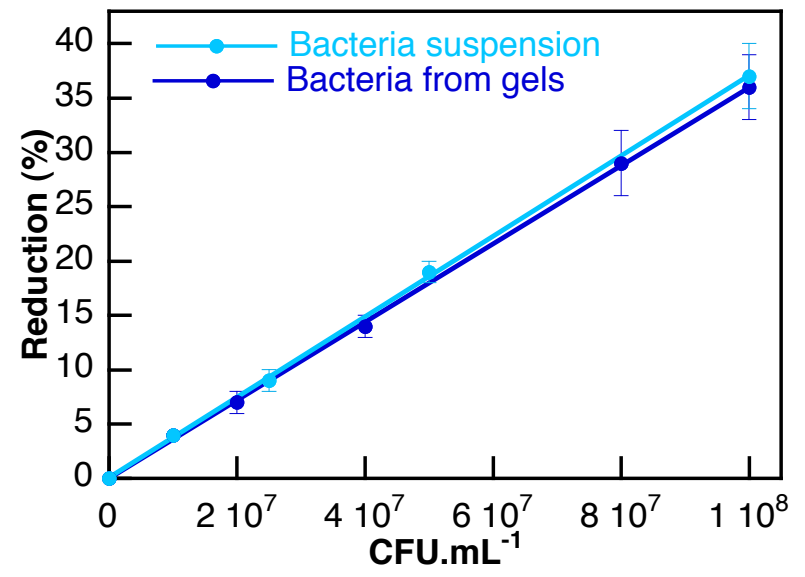

Fig.2 Calibration curve of the Alamar blue reduction as a function of cell density for bacteria suspension and encapsulated cells. Error bars correspond to standard deviation

In a step forward, we evaluated the ATP-metry method, based on the bioluminescent reaction associated with the simultaneous ATP hydrolysis and luciferin oxydation catalyzed by the luciferase enzyme. ${ }^{10}$ Depending on the protocols, intracellular ATP, indicative of cell metabolism, extracellular ATP, assessing cell lysis or both can be measured. ${ }^{11}$ ATP-metry is widely used for microbial assessment of drinking water as well as in toxicology studies. ${ }^{12}$

To avoid the use of the plate count technique, the number of viable cells was estimated from the Alamar Blue test described above; the concentration of intracellular ATP was calculated for $10^{6}$ CFU. As shown in Figure 3, that ATP production was constant over time for encapsulated bacteria and higher than the mean value obtained for the initial bacteria suspension. Since this increase is observed just after encapsulation and does not vary upon ageing, it suggests that the sol-gel reaction itself has an impact on the cell metabolic activity. It is interesting to note that the nearly two-fold increase in ATP production upon encapsulation correlates well with recent demonstration of enhanced fluorescent production in silica-immobilized transformed bacteria. $^{7 b}$ This effect appears irreversible in the conditions of these experiments. However, it must be noticed that ATP-metry applied to bacterial suspension showed high standard deviation $(> \pm 1$ $\mathrm{nM}$ ) so that care must be taken when drawing conclusions.

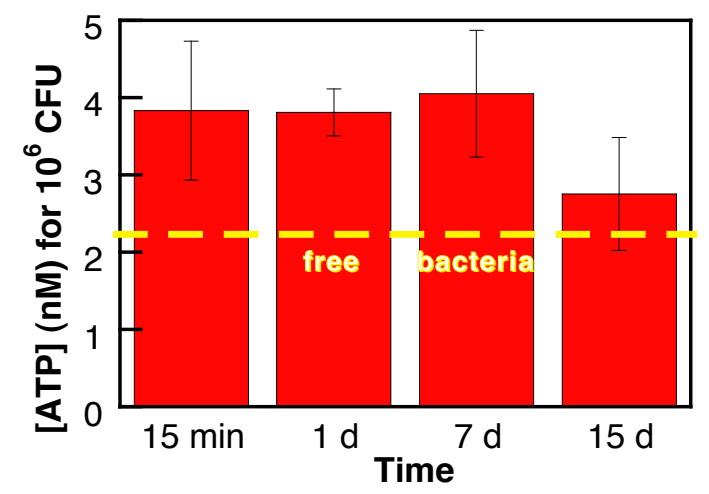

Fig. 3 Evolution of ATP production by encapsulated bacteria. The yellow dashed line corresponds to ATP production by bacteria suspension. Error bars correspond to standard deviation. Yellow dashed line indicates mean value for bacteria suspension.

In this situation, it is not strictly possible to correlate these responses with viability rates taking the bacteria suspension as a reference. However, the evolution of cell viability with time can still be monitored using the $t=15$ min gel sample as a reference. As shown in Fig 4, it then becomes possible to establish a good correlation between plate count, Alamar Blue and ATP-metry measurements. Noticeably, at each time point, there is no statistical difference in relative activity determined by the three methods.

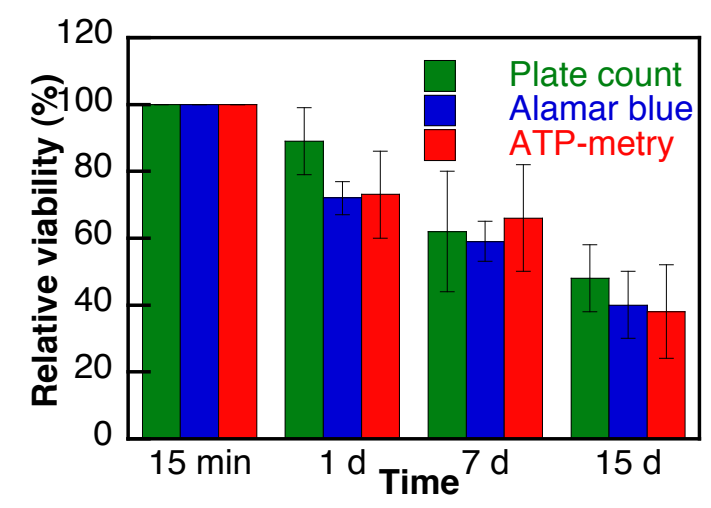

Fig. 4 Comparison of the relative viability of encapsulated bacteria (using $t=15$ min as $100 \%$ ) as determined by the plate count, Alamar blue and ATP-metry. Error bars correspond to standard deviation. 
Hence, the two methods appear highly complementary as the Alamar Blue provides a direct indication on cell viability whereas the ATP-metry reveals a modification of the cell activity. In the present case, where the initial sodium silicate concentration $(0.8 \mathrm{M})$ was significantly higher than in our previous procedure $(0.4 \mathrm{M})^{4}$ in order to compensate for the lack of silica nanoparticles, the observed decrease in viability and increase in ATP production can be attributed to the high ionic strength. ${ }^{13}$ This hypothesis is strengthened by SEM observation of the encapsulated bacteria (Fig. 5) showing large intracellular polyphosphate granules that have been reported in microbial cells as a consequence of high osmotic pressure. ${ }^{14}$

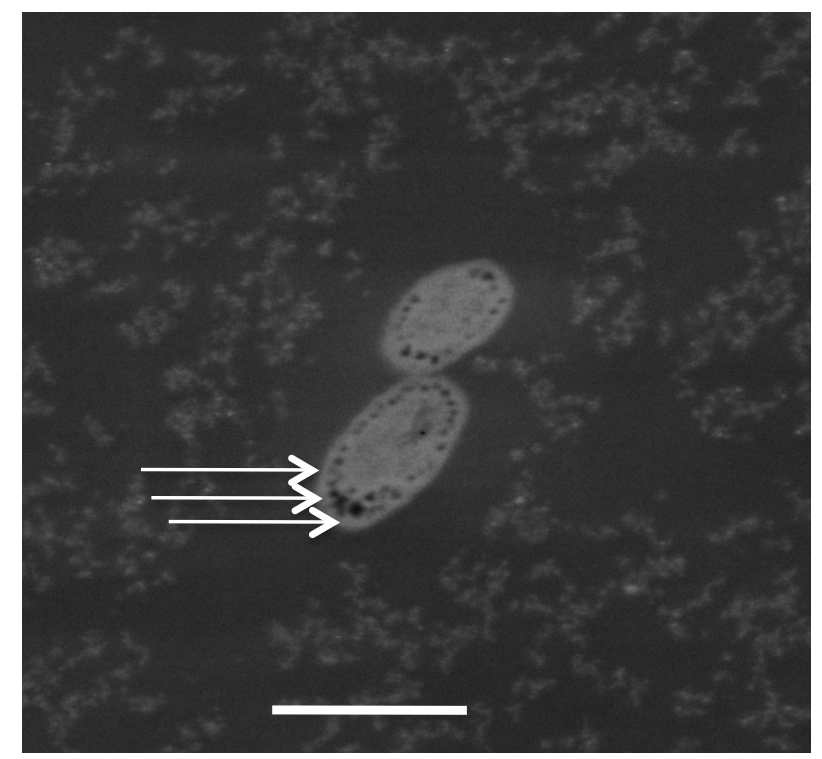

Fig. 5 SEM-FEG image of encapsulated E. coli bacteria. White arrows indicate polyphosphate granules that appear dark under secondary electron imaging. Scale bar $=1 \mu \mathrm{m}$

\section{Conclusions}

Due to their simplicity, robustness and limited experimental time (max. $2 \mathrm{~h} v s .24 \mathrm{~h}$ for plate counting), the Alamar Blue and ATP-metry methods appear very useful for future investigations of sol-gel cell encapsulation. They can be applied to many different organisms in oxic or anoxic conditions, ${ }^{9,12}$ opening the route to inter-species comparison studies. This would be particularly interesting for different prokaryotic phyla, such as Archea or cyanobacteria cells, not only targeting applications for energy production or environmental remediation, ${ }^{15}$ but also for more fundamental issues related to fossilization processes. ${ }^{16}$

\section{Acknowledgments}

M.B. thanks the Région Ile-de-France for funding in the framework of C'Nano IdF. C'Nano-IdF is the nanoscience competence center of Paris Region, supported by CNRS, CEA, MESR and Région Ile-deFrance.

\section{Notes and references}

${ }^{a}$ Sorbonne Universités, UPMC Univ Paris 06, UMR 7574, Laboratoire de Chimie de la Matière Condensée de Paris, F-75005 Paris, France.

${ }^{\mathrm{b}}$ CNRS, UMR 7574, Laboratoire de Chimie de la Matière Condensée de Paris, F-75005 Paris, France. E-mail:thibaud.coradin@upmc.fr; tel: +33144274018; fax:+33-144274769

c Univ Paris Diderot, Sorbonne Paris Cité, Interfaces, Traitements, Organisation et Dynamique des Systèmes (ITODYS), UMR 7086, CNRS, 15 rue Jean de Baïf, F-75205 Paris, France.

${ }^{d}$ Institut de Minéralogie et de Physique des Milieux Condensés (IMPMC), UMR 7590, CNRS, Universités Paris 6 et Paris 7, 140 Rue de Lourmel, Paris, France.

Electronic Supplementary Information (ESI) available: Full experimental protocols of cell encapsulation, plate count, Alamar Blue and ATP-metry, SEM

1 (a) L. J. Rothschild and R. L. Mancinelli, Nature, 2001, 409, 1092; (b) S. R. Vartoukian, R. M. Palmer and W. G. Wade, FEMS Microbiol. Lett., 2010, 309, 1.

2 (a) M. M. Lleo, B. Bonato, M. C. Tafi, C. Signoretto, M. Boaretti and P. Caneri, J. Appl. Microbiol. 2001, 91, 1095; (b) J. D. Oliver, J. Microbiol. 2005, 43, 93

3 S. Heim, M. Del Mar Lleo, B. Bonato, C. A. Guzman and P. Canepari, J. Bacteriol. 2002, 184, 6739.

4 N. Nassif, O. Bouvet, M. Noelle Rager, C. Roux, T. Coradin and J. Livage, Nat. Mater., 2002, 1, 42

5 J. C. Harper, D. M. Lopez, E. C. Larkin, M. K. Economides, S. K. McIntyre, T. M. Alam, M. S. Tartis, M. Werner-Washburne, C. J. Brinker, S. M. Brozik and D. R. Wheeler, Chem. Mater. 2011, 23, 2555.

6 (a) N. Nassif, C. Roux, T. Coradin, O. M. M. Bouvet and J. Livage, J. Mater. Chem., 2004, 14, 2264; (b) G. S. Alvarez, M. L. Foglia, G. J. Copello, M. F. Desimone and L. E. Diaz, Appl. Microbiol. Biotechnol., 2008, 12, 639.

7 (a) J. R. Premkumar, O. Lev, R. Rosen and S. Belkin, Adv. Mater. 2001, 13, 1773; (b) N. M. Eleftheriou, X. Ge, J. Kolesnik, S. B. Falconer, R. J. Harris, C. Khurigara, E. D. Brown and J. D. Brennan, Chem. Mater., 2013, 25, 4798.

8 J. O'Brien, I. Wilson, T. Orton and F. Pognan, Eur. J. Biochem., 2000, 267, 5421.

9 S. N. Rampersad, Sensors, 2012, 12, 12347.

10 A. Ishida, T. Yoshikawa, T. Nakazawa and T. Kamidate, Anal. Biochem., 2002, 305, 236.

11 N. A. Romonova, L. Y. Brovko, J. Moore, E. Pometun, A. P. Savitsky, N. N. Ugarova and M. W. Griffiths, Appl. Environ. Microbiol., 2003, 69, 6393.

12 (a) S. A. Dexter, M. Camara, M. Davies and K. M. Shakesheff, Biomaterials, 2003, 24, 27; (b) C. Lee, J. Kim and S. Hwang, Biodegradation, 2006, 17, 347.

13 M. Perullini, M. Amoura, C. Roux, T. Coradin, M . L. Japas, M. Jobbagy and S. A. Bilmes, J. Mater. Chem., 2011, 21, 4546.

14 M. J. Seufferheld, H. M. Alvarez and M. E. Farias, Appl. Environ. Microbiol., 2008, 74, 5867.

15 (a) A. Léonard, P. Dandoy, E. Danloy, G. Leroux, C. Meunier, J. Rooke and B.-L. Su, Chem. Soc. Rev., 2011, 40, 860; (b) M. Blondeau and T. Coradin, J. Mater. Chem., 2012, 22, 22335; (c) D. J. Dickson and R. L. Ely, Appl. Microbiol. Biotechnol., 2013, 97, 1809. 
16 F. Orange, F. Westall, J.-R. Disnar, D. Prieur, N. Bienvenu, M. Le Romancier and Ch. Défarge, Geobiology, 2009, 7, 403. 